\title{
METODE TRITAWA UNTUK MENINGKATKAN MINAT DAN HASIL BELAJAR MATEMATIKA DI PONDOK PESANTREN
}

\author{
Nurlaili Wahyuni $^{1}$, Lutfiyah ${ }^{2}$, Taufik $^{3}$, Chairul Fajar Tafrilyanto ${ }^{4}$ \\ 1,2,3,4 Pendidikan Matematika, Universitas Madura, Jawa Timur \\ ${ }^{1}$ leliwahyuni62@yahoo.com \\ ${ }^{2}$ fifin3780@gmail.com \\ 3taufik03ismail@gmail.com \\ ${ }^{4}$ chairul_math@unira.ac.id
}

\begin{abstract}
Abstrak: Penelitian ini bertujuan untuk mendeskripsikan aktivitas siswa, minat belajar siswa dan hasil belajar siswa pada pokok bahasan trigonometri di Pondok Pesantren, yang dilaksanakan di kelas XI MA Darul Ulum Pondok Pesantren Banyuanyar dengan jumlah siswa 25 orang. Penelitian ini merupakan penelitian tindakan kelas (PTK), dimana dalam setiap siklus terdiri dari 4 komponen yaitu planning (perencanaan), acting (tindakan), observing (observasi) dan reflecting (refleksi). Rata-rata aktivitas siswa pada pertemuan pertama siklus I sebesar 2,95 dengan kategori Baik sedangkan pada siklus II sebesar 3,46 dengan kategori Baik. Hasil observasi aktivitas siswa pada siklus I dan siklus II di atas menunjukkan adanya peningkatan rata-rata aktivitas siswa dalam pembelajaran menggunakan metode Tritawa sebesar 0,51. Rata-rata respon siswa pada pertemuan pertama siklus I sebesar 82,32\% dengan kategori Positif sedangkan pada siklus II sebesar $87,52 \%$ dengan kategori Positif. Hasil angket respon siswa pada siklus I dan siklus II di atas menunjukkan adanya peningkatan rata-rata angket respon siswa dalam pembelajaran menggunakan metode Tritawa sebesar 5,20\%. Tes hasil belajar siswa pada pertemuan pertama siklus I sebesar 60, dari 25 siswa terdapat 12 siswa dinyatakan tuntas dengan persentase ketuntasan sebesar $48 \%$ sedangkan pada siklus II rata-rata tes hasil belajar sebesar 80,84 , dari 25 siswa terdapat 22 siswa dinyatakan tuntas dengan persentase ketuntasan sebesar $88 \%$. Rata-rata dan persentase ketuntasan hasil belajar siswa pada siklus I dan siklus II di atas menunjukkan adanya peningkatan rata-rata hasil belajar sebesar 20,84 dan persentase ketuntasan sebesar $40 \%$.
\end{abstract}

Katakunci: Metode Tritawa; Hasil Belajar; Trigonometri; Pondok Pesantren.

\begin{abstract}
This study aims to describe student activities, student interest in learning and student learning outcomes on the subject of trigonometry in Islamic Boarding School, which was carried out in class XI MA Darul Ulum Banyuanyar Islamic Boarding School with 25 students. This research is a classroom action research (CAR). Where in each cycle consists of 4 components, namely planning (planning), action (action), observing (observation) and reflection (reflection). The average student activity at the first meeting of the first cycle was 2.95 with the Good category on the second cycle was 3.46 with the Good category. The results of observations of student activity in cycle I and cycle II above show an average increase in student activity in learning using the Tritawa method by 0.51 . The average response of students at the first cycle meeting was $82.32 \%$ with the Positive category while at the second cycle was $87.52 \%$ with the Positive category. The results of the questionnaire responses of students in the first cycle and second cycle above the evaluation of the average difference in the questionnaire responses of students in learning using the Tritawa method of 5.20\%. Student learning outcomes test at the first meeting of the first cycle of 60 , of the 25 students belonging to 12 students were approved thoroughly with a percentage of completeness of $48 \%$ while in the second cycle the average learning achievement test was 80.84 , of the 25 students there were 22 students who could complete with a percentage of completeness of $88 \%$. The average and
\end{abstract}


percentage of completeness of student learning outcomes in cycle I and cycle II above the average difference in learning outcomes by 20.84 and the percentage of completeness by $40 \%$.

Keywords : Tritawa Method; Learning Outcomes; Trigonometry; Islamic Boarding School.

\section{Pendahuluan}

Pendidikan hakekatnya adalah usaha sadar dan terencana untuk mewujudkan suasana belajar dan proses pembelajaran agar siswa secara aktif mengembangkan potensi dirinya untuk memiliki kekuatan spiritual keagamaan, pengendalian diri, kepribadian, kecerdasan, ahklak mulia, serta keterampilan yang diperlukan dirinya, masyarakat, bangsa dan negara. Pendidikan di Indonesia dikenal dengan sistem pendidikan nasional yang dilaksanakan melalui tiga jalur pendidikan, yaitu: (1) Pendidikan formal, merupakan pendidikan yang diselenggarakan di sekolah-sekolah pada umumnya. Jalur pendidikan ini mempunyai jenjang pendidikan yang jelas, mulai dari pendidikan dasar, pendidikan menengah, sampai pendidikan tinggi; (2) Pendidikan informal, merupakan jalur pendidikan keluarga dan lingkungan berbentuk kegiatan belajar secara mandiri yang dilakukan secara sadar dan bertanggung jawab; (3) Pendidikan non formal, merupakan jalur pendidikan di luar pendidikan formal yang dapat dilaksanakan secara terstruktur dan berjenjang. Pendidikan non formal paling banyak terdapat pada usia dini, pendidikan dasar, dan TPA, atau Taman Pendidikan Al-Qur'an, yang banyak terdapat di pedesaan. Salah satunya pondok pesantren.

Pendidikan pesantren merupakan salah satu lembaga pendidikan tertua di Indonesia. Sistem pendidikan di pesantren jauh sebelum kedatangan agama Islam di Indonesia. Sebelum proses penyebaran agama Islam di negeri ini sistem tersebut telah dipergunakan secara umum untuk pendidikan dan pengajaran agama Hindu di Jawa, setelah Islam masuk dan tersebar di Jawa sistem tersebut kemudian diambil oleh Islam.
Walaupun demikian asal-usul pendidikan individual yang dipergunakan dalam pesantren serta pendidikan yang dimulai dengan pelajaran bahasa Arab ternyata dapat ditemukan di Baghdad yang menjadi pusat pemerintahan Islam (Yunus, 1969:31), sehingga Karel Steenbrink menyatakan bahwa sistem pendidikan pesantren berasal dari Hindu itu kurang tepat, karena ternyata sistem tersebut dapat ditemukan di dunia Islam (Yunus, 1969:22).

Seiring dengan perkembangan zaman, berdasarkan fakta yang sudah ada, pondok pesantren tidak hanya belajar ilmu salaf tetapi juga banyak belajar ilmu-ilmu umum seperti: fisika, kimia, biologi dan matematika. Seperti halnya di pondok pesantren Banyuanyar yang ada di Madura yang mengutamakan ilmu agama dan ilmu umum. Ilmu umum di Pondok Pesantren Banyuanyar menjadi salah satu pokok pembelajaran yang sebagian disukai oleh santri. Bahkan ada organisasi khusus GISMI (Generation Of Islamic Scientist) yang berfungsi untuk mengembangkan minat dan bakat belajar mereka. Tetapi masih banyak kesulitan yang dialami oleh siswa, salah satunya adalah kesulitan siswa dalam memahami pelajaran matematika.

Berdasarkan hasil wawancara peneliti dengan guru mata pelajaran matematika di Pondok Pesantren Banyuayar Pamekasan Madura, diperoleh hasil bahwa Guru masih mengajar dengan metode ceramah dan hafalan rumus sehingga penguasaan konsep matematika siswa cenderung lemah. Kurangnya kreativitas guru dalam menggunakan media pembelajaran membuat siswa kurang semangat dalam belajar matematika. Hal tersebut membuat siswa pasif dan berakibat terhadap rendahnya minat belajar siswa. Beberapa siswa yang menganggap matematika merupakan 
mata pelajaran yang sulit untuk dipahami sehingga hasil belajar siswa cenderung rendah di bawah kriteria ketuntasan minimal (KKM). Salah satu materi matematika yang dianggap sangat sulit bagi siswa adalah trigonometri. Hal tersebut ditunjang dengan hasil observasi awal peneliti yang berupa soal tes trigonometri pada 25 siswa, tidak ada siswa yang mencapai KKM dengan perolehan rata-rata nilai siswa sebesar 31,48 dan persentase ketuntasan sebesar $0 \%$. Kesulitan siswa dalam materi tersebut disebabkan metode hafalan saja tidak dapat membuat konsep tersebut bertahan lama dikuasai siswa. Sehingga untuk mengatasi hal tersebut guru harus kreatif dalam pembelajaran, salah satunya menggunakan metode alternatif yang dapat mempermudah belajar materi trigonometri yang didukung didukung dengan alat peraga yang sesuai.

$$
\text { Penggunaan alat peraga }
$$

merupakan aspek dari perkembangan yang menunjuk pada perubahan perilaku sebagai hasil dari praktik dan pengalaman. Sesuai dengan hasil penelitian Nurul Astuty Yensy (2012), Metode pembelajaran itu dikatakan sangat baik, apabila memiliki ciri-ciri sebagai berikut: (1) Hasil itu tahan lama dan dapat digunakan dalam kehidupan oleh siswa kalau hasil pengajaran itu tidak tahan lama dan lekas menghilang, berarti hasil pengajaran itu tidak efektif, (2) Hasil itu merupakan pengetahuan asli atau otentik. Pengetahuan hasil proses belajar mengajar itu bagi siswa seolaholah telah merupakan bagian kepribadian bagi diri setiap siswa, sehingga akan dapat mempengaruhi pandangan dan caranya mendekati suatu permasalahan (Sardiman 2008:49-51). Salah satu metode yang dapat digunakan guru dalam mengenalkan sudut-sudut istimewa trigonometri adalah dengan media dengan konsep jarimatika. Menurut Maria Atik Sunarti Ekowati (2016), jarimatika adalah proses perhitungan matematika cepat dengan jari anda, dengan mengoptimalkan kemampuan jari digunakan untuk menghitung dengan cara yang sangat mudah. Kelebihan jarimatika cepat, nyata, praktis, sederhana, aman dan tidak dilarang digunakan dalam ujian. Berdasarkan hasil penelitian dari Tiarmina Sitio (2017), hasil belajar siswa setelah menggunakan alat jarimatika pada saat observasi data awal sebelum tindakan, hasil belajar siswa diperoleh rata-rata persentase $66,88 \%$ dengan kategori cukup tinggi. Kemudian berdasarkan hasil observasi pada siklus pertama yang menunjukkan bahwa tingkat belajar hasil siswa mencapai dengan rata- rata 69,79\% dengan kategori tinggi. Sedangkan pada siklus ke II terjadi peningkatan mencapai hasil belajar siswa diperoleh rata-rata persentase $78,54 \%$ dengan kategori tinggi peningkatan tersebut seiring dengan peningkatan aktivitas guru dan siswa yang disebabkan karna siswa merasa tertarik dengan metode yang diajarkan oleh guru dengan menggunakan jarimatika. Dengan demikian peneliti sangat berkeinginan untuk menerapkan sebuah metode dengan menggunakan alat peraga berupa tangan, yang dikombinasikan dengan perhitungan sudut-sudut istimewa pada materi trigonometri yang diberi nama metode tritawa. Metode Tritawa adalah metode pembelajaran dengan menggunakan alat peraga berupa tangan untuk menentukan nilai pada sudut-sudut istimewa. Dengan adanya metode tritawa diharapkan semua siswa bisa memahami dan mampu mengembangkan bakatnya pada mata pelajaran matematika khususnya pada materi trigonometri. Langkah pertama yang harus kalian ingat adalah setiap jari diumpamakan sebagai nilai perbandingan trigonometri yang dimulai dari ibu jari menuju kelingking, yaitu ibu jari bernilai 0 , jari telunjuk bernilai $1 / 2$, jari tengah bernilai $1 / 2 \times \sqrt{ } 2$, jari manis bernilai $1 / 2 \times$ $\sqrt{3}$, jari kelingking bernilai 1 . 
Selanjutnya, setiap jari tersebut diumpamakan mempunyai besar sudut yang selalu dimulai dari sudut $0^{\circ}$ dan searah jarum jam. Perhatikan bahwa sela jari antara ibu jari dengan jari telunjuk sebesar $30^{\circ}$, sela jari antara jari telunjuk dengan jari tengah sebesar $15^{\circ}$, sela jari antara jari tengah dengan jari manis sebesar $15^{\circ}$, sela jari antara jari manis dengan jari kelingking sebesar $30^{\circ}$. Sehingga berdasarkan uraian tersebut peneliti tertarik untuk melakukan penelitian untuk melihat aktivitas belajar siswa, minat belajar siswa dan hasil belajar matematika siswa di Pondok Pesantren.

\section{Metode Penelitian}

Penelitian ini merupakan penelitian tindakan kelas (PTK). Menurut Arikurto, dkk (2009:58) bahwa penelitian tindakan kelas adalah penelitian tindakan (action research) yang dilakukan dengan tujuan untuk memperbaiki mutu praktik pembelajaran di kelas. Model atau desain yang digunakan dalam penelitian ini adalah model kemmis dan taggart, dimana dalam satu siklus terdiri dari 4 komponen yaitu planning (perencanaan), acting (tindakan), observing (observasi) dan reflecting (refleksi).

1. Subjek Penelitian

Adapun yang menjadi subjek penelitian dalam penelitian ini adalah siswa kelas XI MA Darul Ulum Pondok Pesantren Banyuanyar dengan jumlah siswa 25 orang, yang dipilih berdasarkan masalah yang dihadapi siswa dalam pembelajaran matematika.

2. Desain Penelitian

Desain penelitian ini akan dilakukan dengan beberapa siklus sampai hasil dan minat siswa dalam pelajaran matematika sesuai dengan target $85 \%$.
Dalam penelitian ini menggunakan beberapa metode pengumpulan data yaitu observasi, angket dan tes.

1. Observasi

Hadi dalam sugiono (2012:145) mengemukakan bahwa observasi merupakan suatu proses yang kompleks, suatu proses yang tersusun dari berbagai proses biologis dan psikologis. Dua diantara yang terpenting adalah proses-proses pengamatan dan ingatan. Observasi dilakukan pada saat proses belajar mengajar berlangsung. Kegiatan yang diamati meliputi aktivitas siswa selama proses pembelajaran. Dalam observasi ini, observasi tinggal mengisi pedoman observasi yang telah dibuat sesuai dengan aspekaspek yang akan diamati. Untuk mengetahui aktivitas belajar siswa dengan menggunakan metode tritawa untuk menentukan nilai sudut istimewa digunakan rumus:

$$
N A=\frac{\sum n}{\sum a} \text { (Arikunto 2009:19) }
$$

Keterangan:

$$
\begin{aligned}
N A= & \text { Nilai akhir } \\
\mathrm{n} & =\text { Nilai setiap aspek yang } \\
& \quad \text { diamati }
\end{aligned}
$$

Dengan kategori penentuan nilai akhir sebagai berikut:

$$
\begin{aligned}
& 0,00-1,49=\text { kurang } \\
& 1,50-2,49=\text { cukup } \\
& 2,50-3,49=\text { baik } \\
& 3,50-4,00=\text { sangat baik }
\end{aligned}
$$

2. Angket

Menurut Sugiono (2012:199), angket atau kuisioner merupakan teknik pengumpulan data yang dilakukan dengan cara memberi seperangkat pertanyaan atau 
pertanyaan tertulis kepada responden untuk dijawabnya. Angket dalam penelitian ini berisikan sejumlah pertanyaan tertulis yang mengungkapkan pengetahuan, sikap dan pendapat siswa tentang penggunaan pembelajaran tritawa. Persentae dari setiap respon minat siswa dihitung dengan rumus:

jumla h respon minat tiap aspek yang muncul jumla $h$ seluru $h$ siswa $x$ 100\% (Trianto 2009:243)

$\begin{array}{rrr}\text { Siswa dikatakan } & \text { berminat } \\ \text { terhadap pembelajaran } & \text { metode }\end{array}$ tritawa. Jika jawaban siswa terhadap pernyataan siswa positif untuk setiap aspek yang direspon pada setiap komponen pembelajaran diperoleh persentase $\geq 70 \%$

3. Tes

Tes yang digunakan dalam penelitian ini berupa dari tes uraian yaitu soal atau pertanyaan yang diajukan pada responden berbentuk uraian, sehingga dengan demikian jawaban yang diinginkan menggunakan rumus yang berbentuk uraian bebas dan di dalam kelas dikatakan tuntas apabila terdapat $85 \%$ siswa yang tuntas belajarnya atau mencapai nilai KKM yaitu 70 . Untuk menentukan ketuntasan belajar siswa dihitung dengan menggunakan persamaan sebagai berikut:

$$
\mathrm{KBI}=\frac{\text { siswa siswa } \text { yang tuntas }}{\text { jumla } h \text { seluru } h \text { siswa }} \times 100 \%
$$

(Trianto, 2009:241)

Keterangan:

$\mathrm{KBK}=$ (Ketuntasan Belajar Klasikal).

\section{Hasil dan Pembahasan}

1. Tahap Pelaksanaan Penelitian Siklus I

Pertemuan pertama dan kedua siklus I dilaksanakan pada hari Rabu, 24 April 2019 dan Kamis, 25 April 2019.

a. Tahap Perencanaan (Planning)

Bahan pembelajaran dan penilaian yang dipersiapkan oleh peneliti, yaitu sebagai berikut: RPP, LKS, Daftar kelompok, Lembar observasi, soal tes dan Lembar angket respon siswa

b. Pelaksanaan Tindakan (Acting)

Pertemuan Pertama Siklus 1

1) Kegiatan Awal Pembelajaran Pembelajaran tentang materi trigonometri untuk menentukan letak nilai sudut istimewa dari $0^{\circ}$ sampai $180^{\circ}$. Pada awal pembelajaran anggota peneliti sebagai pengajar membuka pelajaran dengan mengucapkan salam, melakukan absensi, selanjutnya mempersiapkan penerapan metode tritawa pada materi trigonometri.

2) Kegiatan Inti Pembelajaran Dalam kegiatan ini merupakan tahap pengenalan konsep yang melibatkan siswa secara aktif dalam proses pembelajaran. Durasi waktu dalam kegiatan ini adalah 80 menit dimana pada tahap ini merupakan Langkah ke-1 Membentuk Kelompok. Guru membentuk kelompok yang terdiri dari 6 kelompok dimana dalam setiap kelompok berisikan 4 orang dan satu kelompok diantaranya terdiri dari 5 orang. Langkah 
ke-2 Memahami dan menyelesaikan LKS Guru memberikan LKS pada siswa secara individu, agar siswa dapat dengan mudah memahami maksud dari gambar tangan kiri yang ada pada LKS. Guru menjelaskan contoh 1, 2 dan 3 dimana contoh 1 menentukan $\sin 30^{\circ}$. $\sin 30^{\circ}$ ada di atas ibu jari paling atas dan $30^{\circ}$ berada di atas jari telunjuk sehingga kita harus mengambil nilai perbandingan trigonometri di jari telunjuk paling atas yaitu $\frac{1}{2}$ dan $30^{\circ}$ berada di kuadran I nilai positif sehingga $\sin 30^{\circ}$ adalah positif $\frac{1}{2}$ dengan cara yang sama masalah 2 dan 3 akan diperoleh. Kemudian guru meminta siswa mengerjakan soal latihan nomor 1 secara berkelompok dan langsung membahasnya bersama-sama

Langkah ke-3 Membandingkan dan mendiskusikan jawaban. Dalam hal ini guru memberikan soal latihan nomor 2 untuk dikerjakan secara individu. Setelah selesai, guru meminta siswa untuk berkumpul bersama kelompoknya, lalu memberikan kesempatan kepada siswa untuk membandingkan jawaban bersama kelompoknya. Setelah diskusi kelompok dilakukan, guru memfasilitasi diskusi kelas dengan meminta beberapa siswa (secara bergantian) mewakili kelompoknya untuk menyampaikan jawaban.

Langkah ke-4 Menarik kesimpulan. Dari hasil diskusi kelas, guru meminta siswa untuk menarik kesimpulan mengenai konsep penting yang dipelajari tentang konsep metode tritawa.

3) Kegiatan Akhir Pembelajaran Pada kegiatan ini guru meminta siswa untuk menanyakan apabila ada yang belum dipahami tentang apa yang dipelajari dan menutup pelajaran

Pertemuan Kedua Siklus 1

Pada pertemuan kedua guru tidak menjelaskan materi lagi hanya saja guru memberikan lembar instrumen tes dan lembar respon minat siswa terhadap penggunaan metode Tritawa.

c. Observasi

Observer merupakan orang yang mengamati aktivitas siswa selama pembelajaran. Penelitian ini terdiri dari 3 observer, observer 1 adalah dosen pendamping yaitu Chairul Fajar Tafrilyanto, M.Pd. yang mengamati aktivitas siswa pada kelompok 1 dan 2, observer 2 dan observer 3 yaitu mahasiswa prodi pendidikan matematika Moh. Anwar yang mengamati aktivitas siswa pada kelompok 3 dan 4 dan Abd. Khaliq Aziz yang mengamati aktivitas siswa pada kelompok 5 dan 6. Dari hasil observasi, angket, dan hasil tes peneliti akan mengambil 
keputusan untuk menyusun tindakan selajutnya.

d. Refleksi

Pertemuan Pertama Siklus I

1) Kegiatan Awal Pembelajaran

Dari hasil refleksi dapat disimpulkan bahwa kegiatan siswa pada pertemuan pertama siklus I siswa masih banyak yang kurang aktif, dan kurang memusatkan perhatian terhadap apa yang disampaikan oleh guru. Nampak aktivitas siswa masih banyak yang berbicara sendiri.

2) Kegiatan Inti Pembelajaran

Pada pertemuan pertama siklus I, tindakan pada kegiatan inti pembelajaran meliputi tahap membentuk kelompok, memahami dan menyelesaikan LKS, membandingkan dan mendiskusikan jawaban dan menarik kesimpulan. Hasil refleksi dari keempat tahap tersebut akan diuraikan sebagai berikut:

a) Pada tahap membentuk kelompok, siswa sulit untuk dikondisikan sehingga pembentukan kelompok berlangsung agak lama.

b) Pada tahap memahami dan menyelesaikan LKS, siswa langsung menjawab deskripsi pertanyaan pada LKS dengan kata "kok bisa menggunakan tangan" yaitu dengan tidak mengetahui sebelumnya bahwa tangan juga bisa dijadikan alat untuk menghitung atau menentukan nilai sudut istimewa. Sebagian siswa masih kebingungan dalam memahami gambar tangan yang ada pada LKS. Sebagian besar siswa juga masih belum bisa menyelesaikan soal latihan yang ada pada LKS secara individu dan kelompok. Pada kegiatan ini terlalu banyak memakan waktu sehingga melebihi waktu yang sudah ditentukan. Siswa juga kesulitan dalam memahami penjelasan guru karena guru hanya menggunakan bahasa Indonesia.

c) Pada membandingkan dan mendiskusikan jawaban, beberapa siswa sibuk berbicara sendiri tanpa memperhatikan petunjuk guru untuk mendiskusikan jawaban sesama teman dalam kelompok.

d) Pada tahap menarik kesimpulan, siswa masih belum bisa menarik Kesimpulan. Guru masih berperan dalam membimbing siswa dalam memberi kesimpulan.

3) Kegiatan Akhir Pembelajaran

Siswa masih pasif terhadap apa yang diminta guru ketika meminta siswa untuk bertanya tentang apa yang tidak dimengerti terhadap penggunaan metode Tritawa.

Pertemuan Kedua Siklus I

Pada pertemuan kedua siswa tidak bisa mengerjakan soal 
tes yang berbentuk operasi baik penjumlahan dan pengurangan dalam bentuk akar pada materi trigonometri

2. Tahap Pelaksanaan Penelitian Siklus II

Siklus kedua perlu dilakukan dengan memperhatikan hasil pada siklus pertama yang masih belum mencapai target sesuai dengan harapan peneliti berdasarkan kriteria ketuntasan minimal (KKM). Pertemuan pertama dan kedua siklus II dilaksanakan pada hari Rabu, 1 Mei 2019 dan Kamis, 2 Mei 2019.

a. Tahap Perencanaan (Planning)

Bahan pembelajaran dan penilaian yang dipersiapkan oleh peneliti, yaitu sebagai berikut: RPP, LKS, Daftar kelompok tetap, Lembar observasi siswa tetap, Soal tes yang berbeda siklus I, Lembar angket respon siswa tetap. Pembelajaran menggunakan metode yang sama akan tetapi menggunakan bahasa campuran yaitu bahasa Madura dan bahasa Indonesia agar siswa lebih mudah mengerti apa yang dijelaskan guru dengan menggunakan metode Tritawa. Karena siswa sulit untuk mengerti ketika menggunakan bahasa Indonesia saja.

b. Pelaksanaan Tindakan (Acting)

Pertemuan Pertama Siklus II

1) Kegiatan Awal Pembelajaran

Pembelajaran tentang materi trigonometri untuk menentukan letak nilai sudut istimewa dari $180^{\circ}$ sampai $360^{\circ}$. Pada awal pembelajaran anggota peneliti sebagai pengajar membuka pelajaran dengan mengucapkan salam, melakukan absensi. Selanjutnya mempersiapkan penerapan metode tritawa pada materi trigonometri.

2) Kegiatan Inti Pembelajaran

Dalam kegiatan ini merupakan tahap pengenalan konsep yang melibatkan siswa secara aktif dalam proses pembelajaran. Durasi waktu dalam kegiatan ini adalah 80 menit dimana pada tahap ini merupakan Langkah ke-1 Membentuk Kelompok. Guru membentuk kelompok yang terdiri dari 6 kelompok dimana dalam setiap kelompok berisikan 4 orang dan satu kelompok diantaranya terdiri dari 5 orang. Langkah ke-2 Memahami dan menyelesaikan LKS Guru memberikan LKS pada siswa secara individu, agar siswa dapat dengan mudah memahami maksud dari gambar tangan kiri yang ada pada LKS. Guru menjelaskan contoh 1, 2 dan 3 dimana contoh 1 menentukan sin $225^{\circ}$. $\operatorname{Sin} 225^{\circ}$ ada di atas ibu jari paling atas dan $225^{\circ}$ berada di atas jari tengah sehingga kita harus mengambil nilai perbandingan trigonometri yang ada di jari tengah paling atas yaitu $\frac{1}{2} \sqrt{2}$ dan $225^{\circ}$ berada di kuadran III utuk $\sin \alpha$ nilai negatif sehingga $\sin 225^{\circ}$ adalah $-\frac{1}{2} \sqrt{2}$ dengan cara yang sama masalah 2 dan 
3 akan diperoleh. Kemudian guru meminta siswa mengerjakan soal latihan nomor 1 secara berkelompok dan langsung membahasnya bersama-sama Langkah ke-3 Membandingkan dan mendiskusikan jawaban. Dalam hal ini guru memberikan soal latihan nomor 2 untuk dikerjakan secara individu. Setelah selesai, guru meminta siswa untuk berkumpul bersama kelompoknya, lalu memberikan kesempatan kepada siswa untuk membandingkan jawaban bersama kelompoknya. Setelah diskusi kelompok dilakukan, guru memfasilitasi diskusi kelas dengan meminta beberapa siswa (secara bergantian) mewakili kelompoknya untuk menyampaikan jawaban.

Langkah ke-4 Menarik kesimpulan. Dari hasil diskusi kelas, guru meminta siswa untuk menarik kesimpulan mengenai konsep penting yang dipelajari tentang konsep metode tritawa.

3) Kegiatan Akhir Pembelajaran Pada kegiatan ini guru meminta siswa untuk menanyakan apabila ada yang belum dipahami tentang apa yang dipelajari dan menutup pelajaran

Pertemuan Kedua Siklus II

Pada pertemuan kedua guru tidak menjelaskan materi, guru hanya memberikan lembar instrumen tes dan lembar respon minat siswa terhadap penggunaan metode Tritawa.

c. Observasi

Observer sama pada siklus kedua sama seperti pada siklus pertama.

d. Refleksi

Pertemuan Pertama Siklus II

1) Kegiatan Awal Pembelajaran

Dari hasil refleksi dapat disimpulkan bahwa kegiatan siswa pada pertemuan pertama siklus II siswa sudah aktif dan memusatkan perhatiannya terhadap apa yang disampaikan oleh guru.

2) Kegiatan Inti Pembelajaran

Pada pertemuan pertama siklus I, tindakan pada kegiatan inti pembelajaran meliputi tahap membentuk kelompok, memahami dan menyelesaikan LKS, membandingkan dan mendiskusikan jawaban dan menarik kesimpulan. Hasil refleksi dari keempat tahap tersebut akan diuraikan sebagai berikut:

a) Pada tahap membentuk kelompok, siswa langsung membentuk kelompok sesuai dengan instruksi guru, sehingga pembentukan kelompok tidak berlangsung lama.

b) Pada tahap memahami dan menyelesaikan LKS, siswa langsung menjawab soal menentukan nilai sudut istimewa. Siswa dapat memahami gambar tangan yang ada pada LKS. Sebagian besar siswa sudah 
bisa menyelesaikan soal latihan yang ada pada LKS secara individu maupun kelompok. Kegiatan ini berjalan sesuai dengan waktu yang ditentukan.

c) Pada membandingkan dan mendiskusikan jawaban, siswa membandingkan hasil pekerjaannya dalam satu kelompok dan kelompok lain dengan memperhatikan petunjuk guru.

d) Pada tahap menarik kesimpulan, siswa sudah bisa menarik kesimpulan karena mengerti apa yang disampaikan guru.

3) Kegiatan Akhir Pembelajaran

Siswa lebih aktif terhadap apa yang diminta guru ketika meminta siswa untuk bertanya tentang apa yang tidak dimengerti terhadap penggunaan metode Tritawa.

Pertemuan Kedua Siklus II

Pada pertemuan kedua siswa sudah bisa mengerjakan soal tes yang berbentuk operasi baik penjumlahan dan pengurangan dalam bentuk akar pada materi trigonometri.

Hasil penelitian penggunaan metode Tritawa untuk meningkatkan minat dan hasil belajar matematika di Pondok Pesantren sebagai berikut :

1. Hasil Observasi Aktivitas Siswa

Berdasarkan hasil observasi yang dilakukan oleh 3 orang observer, diperoleh hasil perhitungan rata-rata aktivitas siswa pada pertemuan pertama siklus I sebesar 2,95 dengan kategori Baik sedangkan pada siklus II sebesar 3,46 dengan kategori Baik. Berdasarkan hasil perhitungan yang diperoleh dari hasil observasi aktivitas siswa pada siklus I dan siklus II di atas menunjukkan adanya peningkatan rata-rata aktivitas siswa dalam pembelajaran menggunakan metode tritawa sebesar 0,51 .

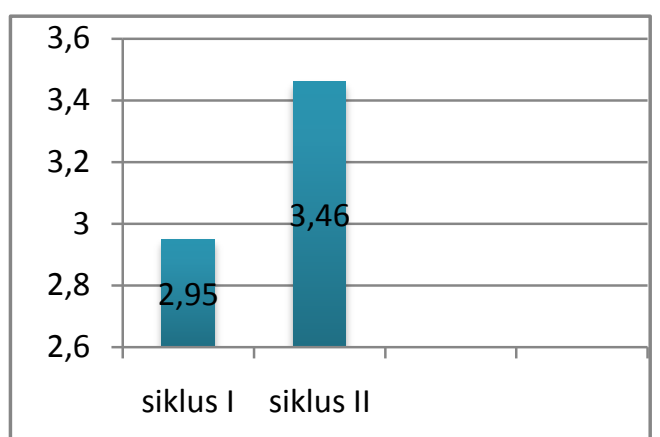

Gambar 1. Diagram Aktivitas Belajar Siswa

2. Hasil Respon Siswa

Berdasarkan hasil angket respon siswa, diperoleh hasil perhitungan rata-rata respon siswa pada pertemuan pertama siklus I sebesar $82,32 \%$ dengan kategori positif sedangkan pada siklus II sebesar $87,52 \%$ dengan kategori positif. Berdasarkan hasil perhitungan yang diperoleh dari hasil angket respon siswa pada siklus I dan siklus II di atas menunjukkan adanya peningkatan rata-rata angket respon siswa dalam pembelajaran menggunakan metode tritawa sebesar $5,20 \%$. 


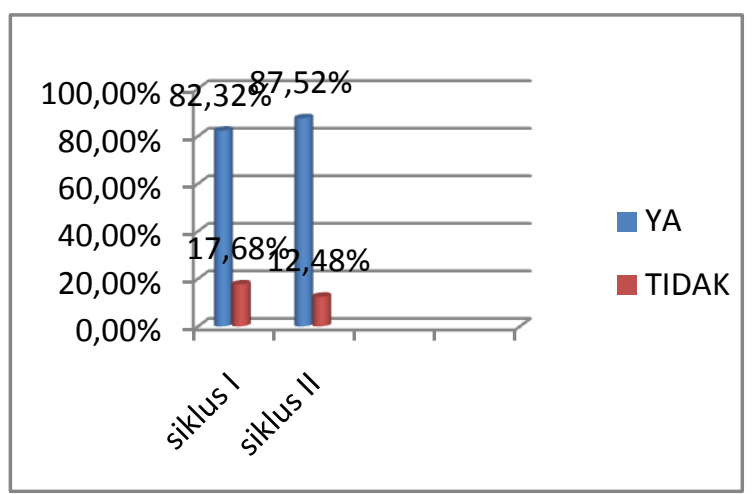

Gambar 2. Diagram Respon Siswa

3. Analisis Data Hasil Tes Hasil Belajar Siswa

Berdasarkan tes hasil belajar siswa, diperoleh hasil perhitungan rata-rata tes hasil belajar siswa pada pertemuan pertama siklus I sebesar 60 , dari 25 siswa terdapat 12 siswa dinyatakan tuntas dengan persentase ketuntasan sebesar $48 \%$ sedangkan pada siklus II rata-rata tes hasil belajar sebesar 80,84, dari 25 siswa terdapat 22 siswa dinyatakan tuntas dengan persentase ketuntasan sebesar $88 \%$. Berdasarkan rata-rata dan persentase ketuntasan hasil belajar siswa pada siklus I dan siklus II di atas menunjukkan adanya peningkatan rata-rata hasil belajar sebesar 20,84 dan persentase ketuntasan sebesar $40 \%$.

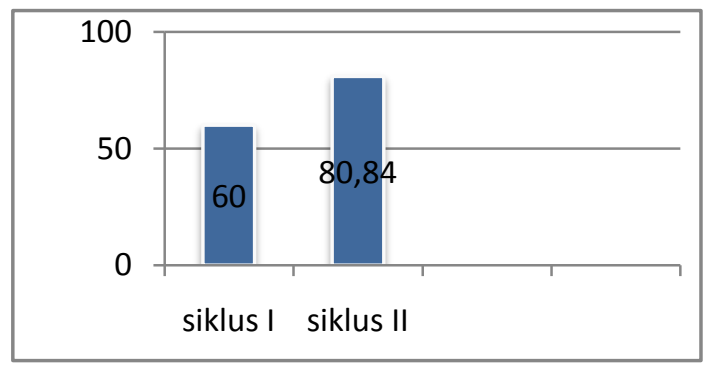

Gambar 3. Diagram Tes Hasil Belajar Siswa

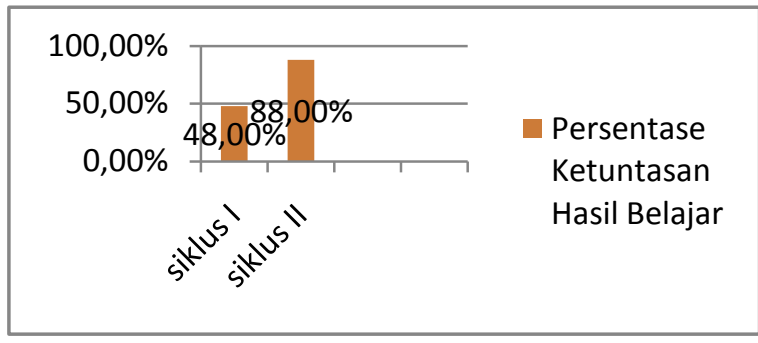

Gambar 4. Diagram Persentase Ketuntasan Hasil Belajar Siswa

Penelitian ini dilakukan di pondok pesantren Banyuanyar Pamekasan Madura berdasarkan observasi awal yang telah dilakukan oleh peneliti. Hasil wawancara menunjukkan guru masih menggunakan metode ceramah dan menghafal sudut-sudut istimewa pada pokok bahasan trigonometri. Hal tersebut menunjukkan kurangnya kreativitas guru dalam menggunakan metode pembelajaran sehingga siswa kurang semangat dalam belajar matematika. Kurangnya semangat siswa dalam belajar matematika ditunjukkan oleh kepasifan siswa yang berakibat rendahnya minat dan hasil belajar siswa. Hal tersebut terbukti oleh hasil belajar siswa yang masih dibawah kriteria ketuntasan minimal (KKM). Menurut siswa mata pelajaran yang sulit adalah trigometri sehingga peneliti melakukan observasi pada 25 siswa di salah satu kelas pada pondok pesantren tersebut diperoleh ratarata nilai siswa sebesar 31,48 dengan persentase ketuntasan sebesar $0 \%$ yang berarti tidak ada satupun siswa yang nilainya mencapai KKM. Untuk mengatasi hal tersebut peneliti ingin menerapkan suatu metode pembelajaran yaitu metode Tritawa (Trigonometri Tangan Dewa), sebuah metode pembelajaran menggunakan alat peraga 
berupa tangan untuk menentukan nilai pada sudut-sudut istimewa.

Hasil penelitian siklus I menunjukkan rata-rata aktivitas siswa sebesar 2,95 dengan katagori baik, akan tetapi siswa masih banyak yang kurang aktif dan kurang memusatkan perhatian terhadap apa yang disampaikan oleh guru. Nampak aktivitas siswa yang berbicara sendiri dan sulit dikondisikan sehingga pembentukan kelompok berlangsung agak lama. Sebagian siswa juga masih kebingungan dalam memahami gambar tangan yang ada pada LKS dan siswa juga masih belum bisa menyelesaikan soal latihan yang ada pada LKS secara individu dan kelompok sehingga guru harus menjelaskan berulang-ulang. Siswa juga kesulitan dalam memahami penjelasan guru karena guru hanya menggunakan bahasa Indonesia sehingga guru menggunakan alternatif untuk menggunakan bahasa campuran yaitu bahasa Indonesia dan bahasa madura. Beberapa siswa sibuk berbicara sendiri tanpa memperhatikan petunjuk guru untuk mendiskusikan jawaban sesama teman dalam kelompok. Siswa masih belum bisa menarik kesimpulan sehingga guru masih membimbing siswa dalam menarik kesimpulan. Siswa masih pasif terhadap apa yang diminta guru ketika meminta siswa untuk bertanya tentang apa yang tidak dimengerti terhadap penggunaan metode Tritawa dalam mengerjakan soal. Pada siklus I respon minat siswa sebesar $82,32 \%$ dengan kategori positif sedangkan rata-rata tes hasil belajar siswa sebesar 60 dengan 12 siswa dari 25 siswa dinyatakan tuntas yang ditujukkan dengan persentase sebesar $48 \%$. Berdasarkan hasil tes tersebut menunjukkan persentase ketuntasan masih belum mencapai persentase ketuntasan sesuai dengan ketuntasan belajar secara klasikal, sehingga perlu dilakukan siklus kedua.

Hasil penelitian siklus II menunjukkan rata-rata aktivitas siswa sebesar 3,46 dengan katagori baik sehingga dapat terlihat peningkatan ratarata aktivitas siswa sebesar 0,51 yang ditunjukkan dengan kegiatan siswa yang mulai aktif dan memusatkan perhatiannya terhadap apa yang disampaikan oleh guru. Siswa langsung membentuk kelompok sesuai dengan instruksi guru, sehingga pembentukan kelompok tidak lagi berlangsung lama. Siswa langsung menjawab soal menentukan nilai sudut istimewa dan mudah memahami gambar tangan yang ada pada LKS. Sebagian besar siswa sudah bisa menyelesaikan soal latihan yang ada pada LKS secara individu maupun kelompok. Kegiatan ini berjalan sesuai dengan waktu yang ditentukan. Siswa dapat membandingkan hasil pekerjaannya dalam satu kelompok dan kelompok lain dengan memperhatikan petunjuk guru. Siswa sudah bisa menarik kesimpulan karena mengerti apa yang disampaikan guru. Siswa lebih aktif terhadap apa yang diminta guru ketika meminta siswa untuk bertanya tentang apa yang tidak dimengerti terhadap penggunaan metode Tritawa. Pada siklus II respon minat siswa sebesar $87,52 \%$ dengan kategori positif yang mengalami peningkatan dibandingkang dengan siklus I sebesar $5,2 \%$, sedangkan rata-rata tes hasil belajar siswa pada pertemuan pertama siklus I sebesar 80,84 dengan 22 siswa dari 25 siswa dinyatakan tuntas yang ditujukkan dengan persentase $88 \%$. Dapat terlihat bahwa rata-rata tes hasil belajar meningkat sebesar 20,84 sedangkan persentase ketuntasan secara klasikal meningkat sebesar $40 \%$. Berdasarkan hasil observasi aktivitas siswa, respon 
minat siswa dan hasil belajar siswa yang mengalami peningkatan dengan menggunakan metode tritawa pada pokok bahasan trigonometri. Sesuai dengan hasil penelitian Nurul Astuty Yensy (2012), metode pembelajaran itu dikatakan sangat baik ketika itu hasilnya tahan lama dan dapat digunakan dalam kehidupan oleh siswa. Dengan menggunakan metode Tritawa pengetahuan siswa kemungkinan besar akan tahan lama karena pada akhirnya akan terbiasa tidak akan menggunakan alat peraga kembali. Siswa dapat menggunakan tangannya langsung dalam menggunakan metode tritawa untuk menghitung sudut-sudut istimewa dalam trigonometri. sehingga metode tritawa dapat digunakan dalam ujian dengan cepat, nyata, praktis, sederhana, aman dan tidak dilarang digunakan dalam ujian sesuai dengan penelitian Maria Atik Sunarti Ekowati (2016). Maka dari itu, penelitian sudah berhasil sesuai kriteria yang ditetapkan peneliti dan tidak perlu lagi dilanjutkan pada siklus berikutnya.

\section{Kesimpulan}

Metode Tritawa dapat meningkatkan minat dan hasil belajar siswa pada pokok bahasan Trigonometri sebagai berikut :

1. Hasil observasi dari aktivitas belajar siswa meningkat dari siklus I ke siklus II sebesar 0,51 dari 2,95 dengan kategori baik menjadi 3,46 dengan kategori baik.

2. Hasil observasi dari aktivitas belajar siswa meningkat dari siklus I ke siklus II sebesar 0,51 dari 2,95 dengan kategori baik menjadi 3,46 dengan kategori baik.

3. Hasil belajar siswa meningkat dari siklus I ke siklus II dengan rata-rata sebesar 20,84 dengan persentase ketuntasan klasikal sebesar $40 \%$ dari rata-rata sebesar 60 dengan ketuntasan klasikal sebesar $48 \%$ menjadi rata-rata sebesar 80,84 dengan ketuntasan klasikal sebesar $88 \%$. Sehingga dikatakan tuntas karena telah melebihi $85 \%$ ketuntasan secara klasikal.

Berdasarkan kesimpulan yang telah diperoleh, saran yang bisa peneliti sampaikan adalah:

1. Apabila ingin Metode Tritawa pada pokok bahasan trigonometri sebaiknya dipersiapkan sebaik mungkin seperti pembentukan kelompok disusun sebelum pembelajaran dimulai sehingga lebih mengoptimalkan waktu dalam pembelajaran.

2. Peneliti lain yang ingin melakukan penelitian serupa dengan menerapkan Metode bisa dilaksanakan pada subjek yang berbeda atau materi pelajaran yang berbeda sehingga dapat menambah referensi tentang keefektifan penggunaan Metode Tritawa.

\section{Ucapan Terimakasih}

Kepada Simbelmawa Ristekdikti atas pendanaan Program Kreativitas Mahasiswa (PKM) skim Penelitian dengan No. DIPA-042.04.1400170/2019.

\section{Dafar Rujukan}

Astuty, Yensy, Nurul. 2012. Penerapan Model Pembelajaran Kooperatif Tipe. Examples Non Examples Dengan Menggunakan Alat Peraga Untuk Meningkatkan Hasil Belajar Siswa Di Kelas VIII SMPN 1 Argamakmur

Amirah, Budiastuti, Siti. 2012. Eksperimentasi Model Pembelajaran Kooperatif Think Pair Share Dan Team Assisted Individualization Pada Materi Trigonometri Ditinjau Dari Minat Belajar Matematika Siswa Smk Di Kabupaten Ponorogo Tahun Pelajaran 2011/2012 
Ekowati, Sunarti, Atik, Maria. 2016 .prototyphe development model application visualization jarimatika simple and interest based website for early childhood education.

Hamdani, Dedy. 2012. Pengaruh Pembelajaran Generatif Dengan Menggunaka Alat Peraga Terhadap Pemahaman Konsep Cahaya Kelas Di VIII di SMP Negeri 7 Kota Bengkulu.

Musanna, Al. 2017. Indegenezing Education:Rationalition Toword Revitalization Of $\mathrm{Ki}$ Hadjar Dewantara Educational Praxis

Muttaqien, Dadan Muttaqien. 1999. Sistem Pendidikan Pondok Pesantren (Sebuah Alternatif Mengatasi Kegagalan Sistem Pendidikan Barat).
Putri, ardiyanthi risky. 2017. Penerapan alat peraga jarimatika untu menentukan nilai perbandingan trigonometri sudut-sudut istimewa dalam pembeajaran matematika.

Rampisela, Iriani, Deisa. 2017. Hubungan Kecerdasan Emosional Dan Kecerdasan Spiritual Dengan Prestasi Belajar Siswa di SMP Katolikst. Fransiskus Pineleng.

Sitio, Tiarmina. 2017. Penerapan Metode Jarimatika Untuk Meningkatkan Hasil Belajar Matematika Siswa Kelas 1 SDN Pagaran Tapah Darussalam Kabupaten Hulu.

Tarigan, Daitin. 2014. Penggunaan Teknik Jarimatika Untuk Meningkatkan Keterampilan Berhitung Peserta Didik SD Negri 101774 Sampali Percut Seituan. 